\title{
Performance Characteristics of Self-Excited Induction Generator fed Current Source Inverter for Wind Energy Conversion Applications
}

\author{
M.Sasikumar ${ }^{1}$ and S.Chenthur Pandian ${ }^{2}$
}

\begin{abstract}
This paper presents a performance characteristics and harmonic analysis of self -excited induction generator (SEIG) fed current source inverter for isolated wind energy conversion system. The induction generator, solid state power electronic converter devices and inductor filter components are modeled by using MAT LAB / SIMULINK. In the growing applications and environmental conditions, various types of technologies are introduced to delivering the quality of power to the grid. The main objective of the paper is to track and extract maximum power to the grid connected wind energy conversion system. The current source inverters are used to achieve boost operation with the help of series inductor. The variable voltage, variable frequency supply at the generator terminals is rectified and inverted using power electronic converters. The modulation index of the proposed inverter is adjusted, and to obtained the maximum output power. The experimental results of the SEIG output are compared with the simulation results.
\end{abstract}

Index Terms-Self-Excited Induction Generator (SEIG), Current Source Inverter (CSI), Wind Turbine, wind Energy conversion Scheme (WECS), Isolated Load.

\section{INTRODUCTION}

Wind Energy is one of the major sources of renewable sources. It has non-polluting and economically viable. The wind turbine generator system is producing electricity from varying wind velocity conditions. It is the fastest growing energy technology in the world. Today, the wind turbine market is mixed and types of innovative technologies are available for generator and for power electronics converters, as it improving the wind power production performance. The third generation of power electronic is currently is in progress through the integration of power devices with intelligent circuit, isolation, protection. The digital computation system is making it easier to integrate PWM techniques, signal estimation and complex algorithm for control of machines.

The SEIG become the most widely used wind turbine systems for low cost rugged machine. The generated speed of the induction generator is mainly depending on the wind velocity conditions and modulation index. Due to the economical view and reliable characteristics, the CSI topologies are adopted for various applications based on the

M.Sasikumar is with the Department of Electrical and Engineering Engineering, Sathyabama University, Chennai,600 119 Tamil Nadu, India, (e-mail: pmsasi77@yahoo.co.in).

S.Chenthur Pandian is the Principal, Dr.Mahalingam College of Engineering \& Technology, Udumalai Road, Pollachi - 642003, Tamil Nadu, India (e-mail: chenthur@rediffmail.com). performance merits such as simplicity, ruggedness, cost effectiveness, and very low switching losses. The various PWM techniques are used to get desire voltage in the inverter terminals. Two types of control signals can be applied to the MOSFET switches. $180^{\circ}$ and $120^{\circ}$ conduction modes are the types to produce required output voltage. In current source inverter has simple control circuit and good efficiency but it produces pulsating torque at low speed and they cannot handle small capacity motors. The variable output voltage of the generator is rectified and inverted using the PWM inverter. The modulation index is adjusted such that the voltage at the output is maintained. The self excited squirrel cage induction generators are widely used for wind energy applications, because of their lower maintenance, robustness, simplicity, economy and reliability [2]. The generator uses squirrel cage rotor which do not need DC excitation, unlike synchronous generators.

\section{SySTEM CONFIGURATION}

In this proposed system, a power generation system consisting of a wind turbine with a SEIG connected to the isolated load through a power electronic converter is considered. The variable output voltage from the generator is first rectified using diode bridge rectifier and then inverted by using PWM inverter. In these three phase inverter system consists of six MOSFETS. Three phase inverters are normally used for medium and high power applications. Shunt capacitor is used in the dc link; it acts as a low impedance voltage source. Each switch conducts for $120^{\circ}$. Only two switches remain on at any instant of time. The conduction sequence of switches is $61,12,23,34,45$, 56, and 61. The output power of SEIG depends upon the wind velocity of the horizontal axis wind turbine. Excitation capacitors are used to reduce the reactive power burden of induction generators [4]. The value of capacitance is to determine the output power production of SEIG. The variable magnitude and variable frequency output is given to the power electronic converters. The voltage source inverter is used to get constant voltage, constant frequency. CSI is used as boost operation of inverter. The dc link voltage ripples in the rectifier output is filtered using shunt capacitor filter. The pulse width modulation technique is used to control the inverter output voltage and frequency. It is also affected by the EMI noise. The block diagram of the system is shown in Fig. 1. 


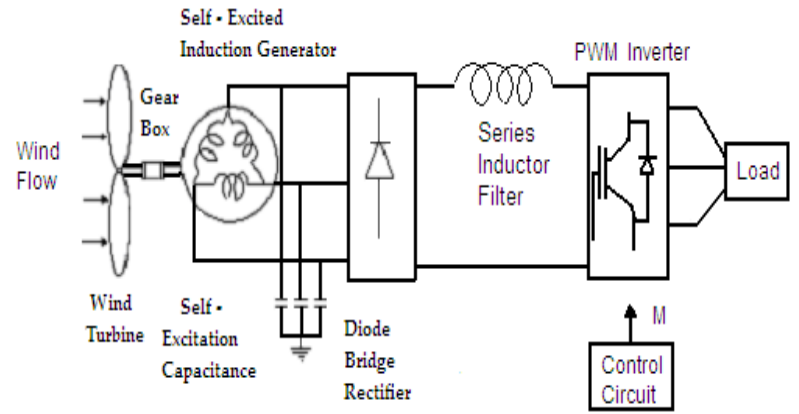

Fig 1 Block Diagram of the voltage source inverter fed Isolated Wind Energy Conversion System

\section{A. Wind turbine}

The kinetic energy in the varying wind velocity is converted into mechanical energy by the wind turbine rotor. The rotor blades are made up of reinforced glass fibre, which is mounded on a steel shaft. The wind turbine may be stall-regulated machine or pitch regulated machine. For stall-regulated machines this pitch angle is fixed at the time of installation whereas in pitch regulated machine, it varies for various wind velocities to maintain the output power constant at rated value.

$$
\begin{aligned}
\text { Kinetic Energy } & =0.5 \rho \mathrm{A} \mathrm{V} . \mathrm{V}^{2} \\
& =0.5 \rho \mathrm{A} \mathrm{V}^{3}
\end{aligned}
$$

The output power of wind turbine is given by

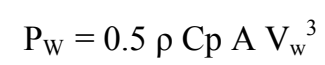

$\mathrm{C}_{\mathrm{p}}$ is expressed as a function of $(\lambda)$

$$
\lambda=\frac{\mathrm{R} \omega_{t}}{V_{w}}
$$

Dimension less power co-efficient $\mathrm{C}_{\mathrm{p}}$

$$
\mathrm{C}_{\mathrm{p}}=0.5\left[\frac{116}{\lambda_{1}}-0.4 \beta-5\right] e^{\frac{-16.5}{\lambda_{1}}}
$$

\section{B. Self-Excited Induction Generator}

The voltage developed in the induction generator due to the residual magnetism. The terminal voltage will build up from small value to a rated value over a period of several seconds [9]. When the slip becomes negative, the output power and developed torque changes from positive to negative, which indicates the motor has become a generator. The dynamic characteristics of SEIG can be represented by the electromechanical equation derived in the synchronously rotating q-d reference frame [1]-[5].

$$
\begin{gathered}
\mathrm{pi}_{\mathrm{qs}}=-\mathrm{K}_{1} \mathrm{r}_{1} \mathrm{i}_{\mathrm{qs}}-\left(\mathrm{i}_{\mathrm{qs}} / \mathrm{Cv}_{\mathrm{ds}}+\mathrm{K}_{2} \mathrm{~L}_{\mathrm{m}} \mathrm{W}_{\mathrm{m}}\right) \mathrm{i}_{\mathrm{ds}}+\mathrm{K}_{2} \mathrm{r}_{2} \mathrm{i}_{\mathrm{qr}}-\mathrm{K}_{1} \mathrm{~L}_{\mathrm{m}} \mathrm{W}_{\mathrm{m}} \mathrm{i}_{\mathrm{dr}} \\
\mathrm{pi}_{\mathrm{ds}}=\left(\mathrm{i}_{\mathrm{qs}} / \mathrm{CV}_{\mathrm{ds}}+\mathrm{K}_{2} \mathrm{~L}_{\mathrm{m}} \mathrm{W}_{\mathrm{m}}\right) \mathrm{i}_{\mathrm{qs}}-\mathrm{K}_{1} \mathrm{r}_{1} \mathrm{i}_{\mathrm{ds}}+\mathrm{K}_{1} \mathrm{~L}_{\mathrm{m}} \mathrm{W}_{\mathrm{m}} \mathrm{i}_{\mathrm{qr}}+\mathrm{K}_{2} \mathrm{r}_{2} \mathrm{i}_{\mathrm{dr}}- \\
\mathrm{K}_{1} \mathrm{v}_{\mathrm{ds}} \\
\mathrm{pi}_{\mathrm{qr}}=-\mathrm{K}_{2} \mathrm{r}_{1} \mathrm{i}_{\mathrm{qs}}+\mathrm{L}_{1} \mathrm{~K}_{2} \mathrm{~W}_{\mathrm{m}} \mathrm{i}_{\mathrm{ds}}-\left(\mathrm{r}_{2}+\mathrm{K}_{2} \mathrm{~L}_{\mathrm{m}} \mathrm{r}_{2}\right) \mathrm{L}_{2} \mathrm{i}_{\mathrm{qr}}+\left(\mathrm{K}_{1} \mathrm{~L}_{1} \mathrm{~W}_{\mathrm{m}}-\right. \\
\left.\mathrm{i}_{\mathrm{qs}} / \mathrm{Cv}_{\mathrm{ds}}+\right) \mathrm{i}_{\mathrm{dr}}
\end{gathered}
$$

$$
\begin{gathered}
\mathrm{pi}_{\mathrm{dr}}=-\mathrm{L}_{1} \mathrm{~K}_{2} \mathrm{~W}_{\mathrm{m}} \mathrm{i}_{\mathrm{qs}}+\mathrm{K}_{2} \mathrm{r}_{1} \mathrm{i}_{\mathrm{ds}}-\left(\mathrm{L}_{1} \mathrm{~K}_{1} \mathrm{~W}_{\mathrm{m}}-\mathrm{I}_{\mathrm{qs}} / \mathrm{Cv}_{\mathrm{ds}}\right) \mathrm{i}_{\mathrm{qr}}+\left(\mathrm{r}_{2}+\right. \\
\left.\mathrm{K}_{2} \mathrm{~L}_{\mathrm{m}} \mathrm{r}_{2}\right) \mathrm{L}_{2} \mathrm{i}_{\mathrm{dr}}+\mathrm{K}_{2} \mathrm{~V}_{\mathrm{ds}}
\end{gathered}
$$

\section{Diode Bridge Rectifier and DC Link}

Three phase diode bridge rectifier is used to convert variable magnitude, variable frequency voltage at the induction generator terminal into DC voltage [3].

The output voltage is expressed as

$$
\operatorname{Vr}=(3 \sqrt{2} / \pi)(\sqrt{3} / \sqrt{2}) * V_{d s} * n_{i}
$$

Input transformer's turns ratio is $1: \eta_{\mathrm{i}}$ The series reactor (L) and shunt reactor (C) acts as an input filter. The current ripples and voltage ripples are reduced by using the above components [5].

Dc Link current is governed by the following equation

$$
p i_{d c}=\left(1 / L_{d c}\right)\left(V_{r}-V_{i}-r_{d c} i_{d c}\right)
$$

Where, $\mathrm{R}_{\mathrm{DC}}$ and $\mathrm{L}_{\mathrm{DC}}$ are the reactor resistance and inductance respectively.

\section{PWM Inverter}

The output power of the rectifier is filtered by using the LC filter. By using PWM inverter DC power is converted into $\mathrm{AC}$ power employing double edge sinusoidal pulse width modulation technique [5]. The PWM signals are used to switch on the IGBT's in the inverter. The IGBT's are connected anti parallel with the diodes. If diode conducts, energy is fed back to the source. A carrier wave is compared with the reference signal corresponding to a phase to generate gating signals. The instantaneous line - to - line output voltage is $\mathrm{V}_{\mathrm{ab}}=\mathrm{V}_{\mathrm{S}}\left(\mathrm{g}_{1}-\mathrm{g}_{3}\right)$.

\section{RESUlTS AND DiSCUSSION}

The current source inverter with wind driven self excited induction generator fed WECS is simulated using MAT LAB/SIMULINK and the results are presented. The minimum and maximum value of the self-excitation capacitance requirement is previously [7]. The d-q model of the self-excited induction generator is used to understand the all characteristics behavior of the generator system. The Simulink model of the SEIG fed current source inverter with RL load is shown in Fig. 2.

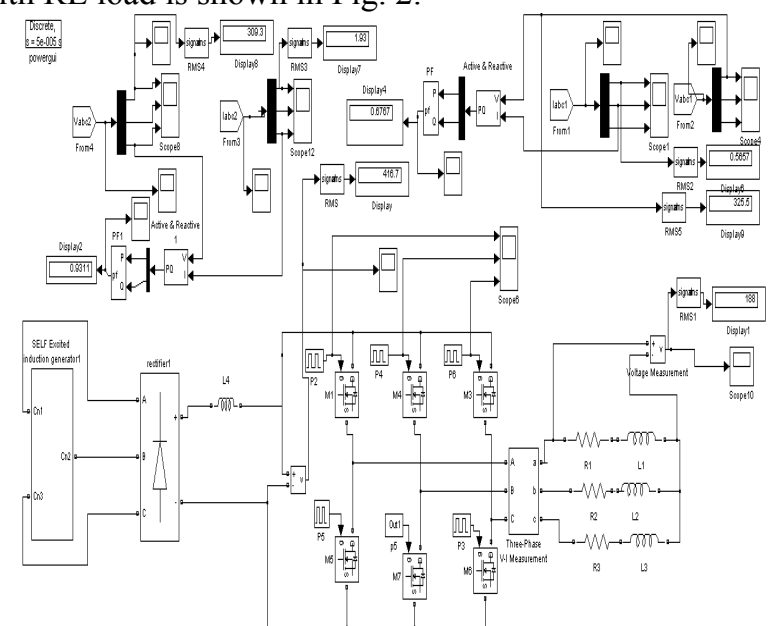

Fig 2 Simulink Model of the SEIG fed current source inverter with RL load

The wind driven induction generator generates 353 volts. The output voltage waveforms of the SEIG is shown in Fig. 
3.

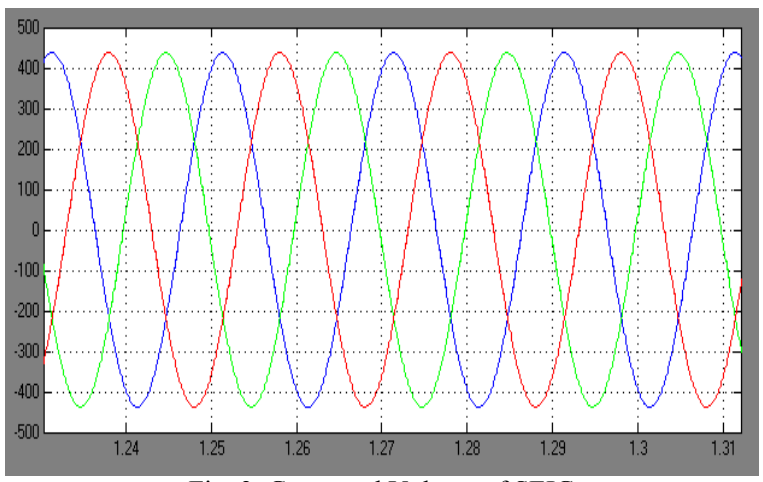

Fig. 3. Generated Voltage of SEIG

The SEIG output voltage is converted into DC voltage by using the uncontrolled rectifier circuits. The output voltage of the rectifier is 350 volts. This DC voltage is given to the three phase current source inverter. The inverter is used to produce required output voltage. Here, the inverter output voltage of 268 volts is applied to the RL load. The phase voltage of the inverter is shown in Fig. 4.

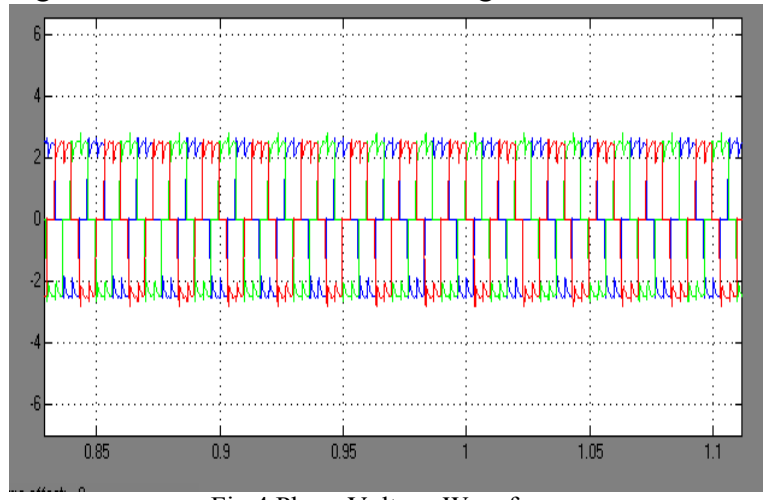

Fig.4 Phase Voltage Waveform

The inverter output line current of Ia, Ib, Ic are shown in Fig. $5 \&$ Fig. 6. In this simulation analysis, the value of the load $\mathrm{R}=25 \mathrm{ohm}$ and $\mathrm{L}=350 \mathrm{mh}$.

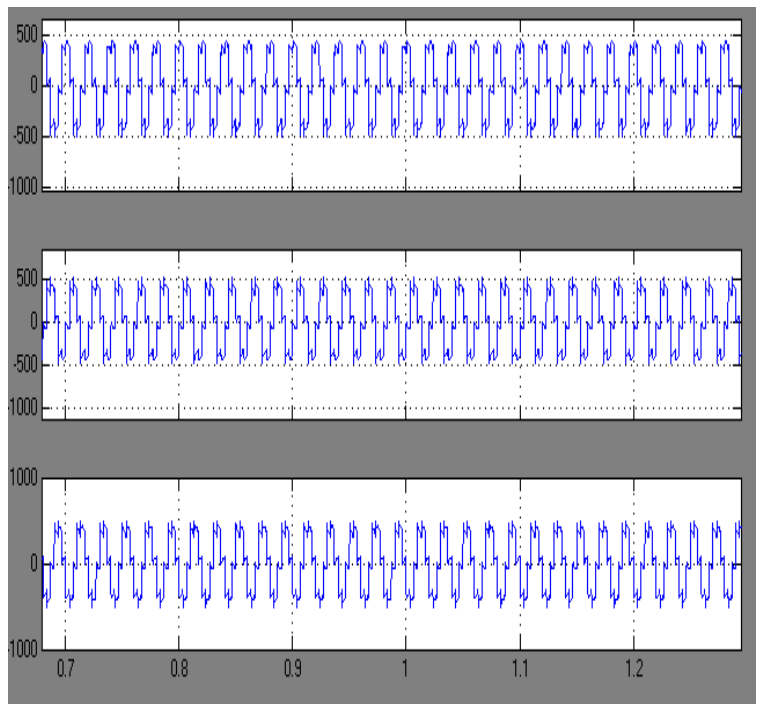

Fig. 5 Line Current Waveform

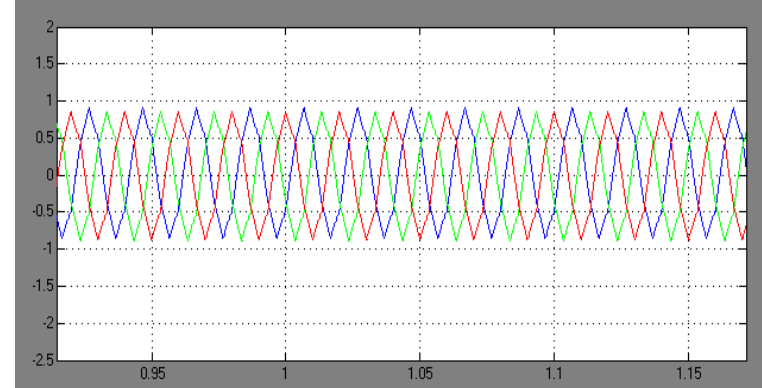

Fig.6 Inverter Output Voltage waveforms

The output voltage of the RL load is shown in Fig. 7. The harmonics presented in a output voltage is mainly depending upon the inductance value. The harmonic spectrum of the inverter current is shown in Fig. 8. The THD value is $5.53 \%$.

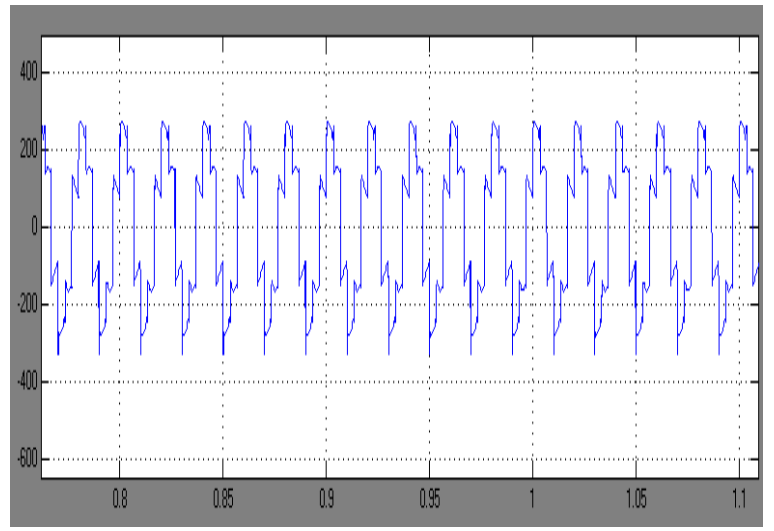

Fig. 7 Load Voltage Waveforms

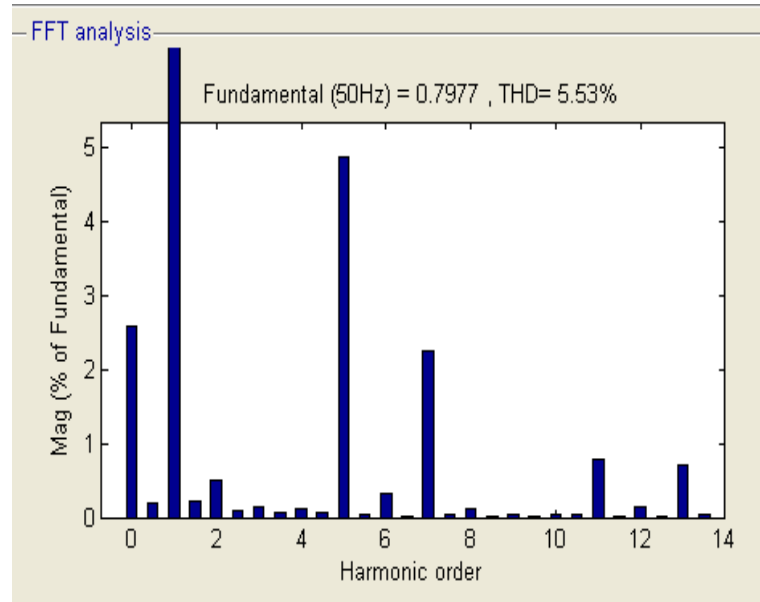

Fig. 8 Harmonic Spectrum

The Simulink model of the SEIG fed CSI for induction motor is shown in Fig. 9.

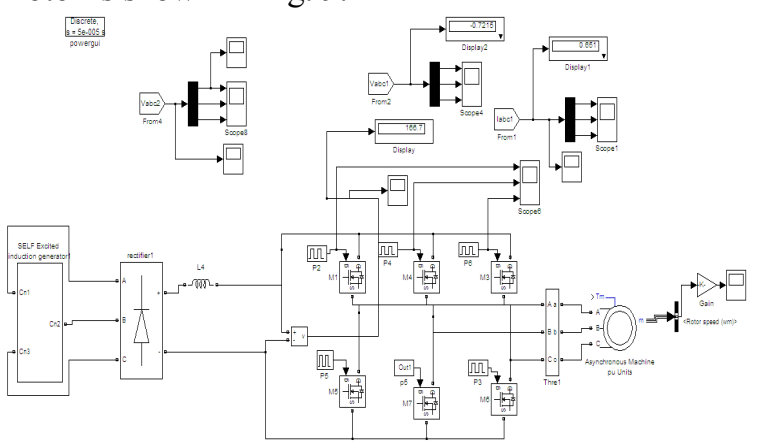

Fig. 9 Simulink Model of SEIG fed CSI with RL load

The generated voltage of the SEIG is 232 volts. The SEIG voltage is shown in Fig. 10. The SEIG voltage is 
rectified into 167 volts by using the uncontrolled rectifier. The output voltage of the inverter is 202 volts. The phase current of 3.8 amps is shown in Fig. 11.

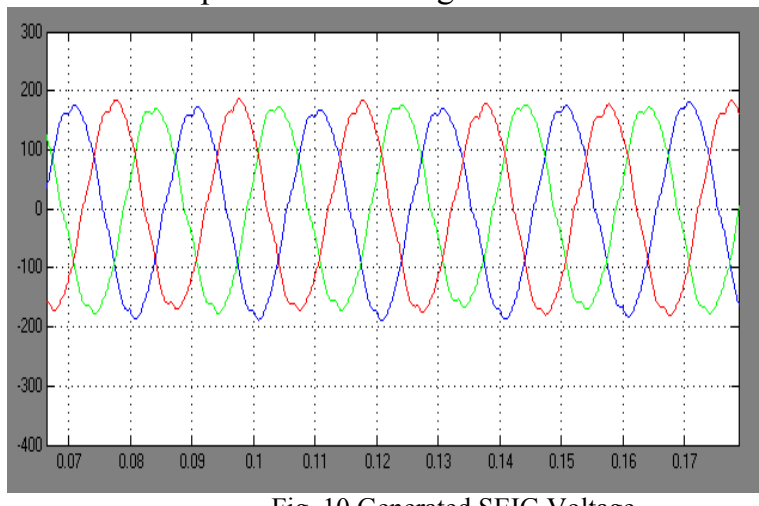

Fig. 10 Generated SEIG Voltage

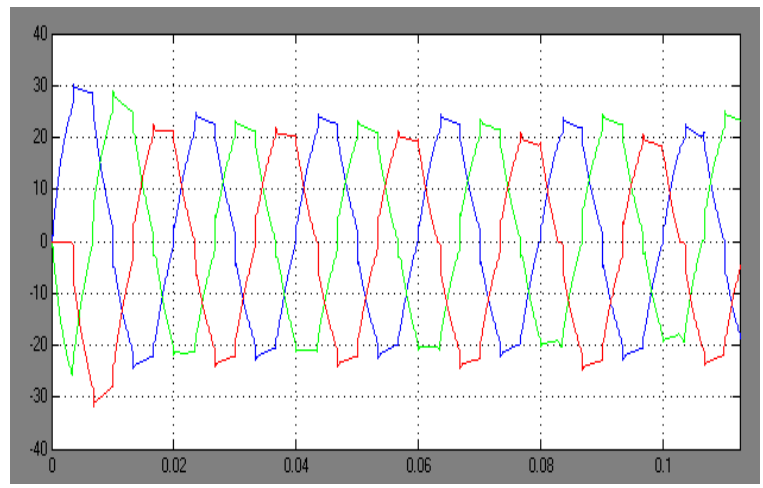

Fig. 11 Phase Current Waveform

The induction motor speed is mainly depending on the inverter voltage. The harmonics interruption in the induction motor load system is high. The THD value is $5.85 \%$. the harmonic spectrum of the motor load system is shown in Fig. 12.

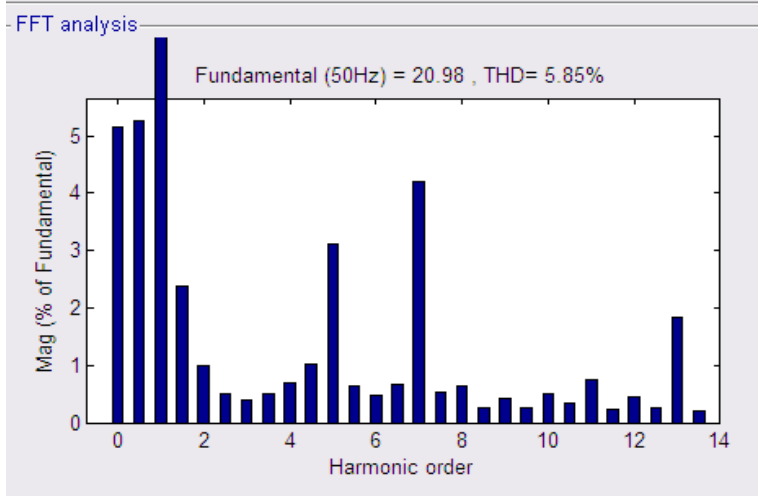

Fig.12. Harmonic Spectrum

\section{CONCLUSION}

The performance analysis and simulation results of a SEIG fed CSI for wind energy conversion system have been described. A wide variation in the output voltage and supply frequency is observed for varying wind velocities and load conditions. Therefore, a DC link converter is introduced in the WECS model, and the effect of modulation index on the generated power is studied for a given wind velocity and load. The simulation results demonstrate the advantages of various modulation schemes. Finally, the operation of the model to simulate both induction motor load and RL load has been shown for different applications. The dynamic voltage, current, rectifier voltage and harmonic spectrum waveforms are developed and analyzed.

\section{REFERENCES}

[1] Dawit S Eyaum Colin Grantham, and Muhammed Fazlur Rahman,"The dynamic characteristics of an isolated self-excited induction generator driven by a wind turbine", IEEE, Transaction on Industry applications, Vol. 39.No.4, July/August 2003 pp 936 - 944.

[2] Yaser Anagreh "Steady state performance of series DC motor powered by wind driven self-excited induction generator," Rev. Energ. Ren: power Engineering, 2001,pp 9-15.

[3] Andrew Miller, Edward Muljadi and Donald S. Zinger, "A Variable Speed Wind Turbine Power Control", IEEE, Transaction on Energy Conversion, Vol. 12.No.2 June 1997, pp - 181- 186.

[4] Rohin M. Hilloowala and Adel M. Sharaf, "A Rule-Based Fuzzy Logic Controller for a PWM Inverter in a Stand alone Wind Energy Conversion Scheme" IEEE, Transaction on Industry Applications, Vol. 32.No.1 January/February 1996, pp 57- 65.

[5] T.F. Chan." Capacitance requirements of self-excited induction generators “, IEEE Transactions on Energy Conversion, Vol. 8, No. 2, June 1993 pp 304-311.

[6] Tarek Ahmed, Osamu Noro, Kazuya Matsuo, Yuji Shindo, and Mutsuo Nakaoka, "Minimum Excitation Capacitance Requirements For Wind Turbine Coupled Stand-alone Self-Excited Induction Generator With Voltage Regulation Based On SVC", Proceedings of IEEE, INTELEC, 2003, pp 396 - 403.

[7] Li Wang, Chaing-Huei Lee, "A novel analysis on the performance of an Isolated self excited induction generators," IEEE Trans. on Energy conversion June 1993, vol.12, No.2.

[8] Rohin M.Hilluwala and Sharaf.A,M "Modeling, Simulation and Analysis of variable speed constant frequency wind energy conversion scheme using self excited induction generator," IEEE Trans. on Energy conversion, 1991.

[9] Al-Bahrani.A.H and Malik.N.H.,"Steady state analysis and performance characteristics of a three phase induction generator self excited with a single capacitor," IEEE Trans. on Energy conversion, December 1990,vol.5, No.4.

[10] F. Giraud and Z. M. Salameh,"Wind-driven variable-speed, variable frequency, double-output, induction generators," Electric Mach. Power Syst., vol. 26, pp. 287-297, 1998.

[11] M. N. Eskander and M. T. El-Hagry,"Optimal performance of double output induction generator used in WECS," Electric Mach. Power Syst.,vol. 25, pp. 1035-1046, 1997.

[12] Singh, S. P., B. Singh, and M. P. Jain, "Comparative study on the performance of commercially designed induction generator with induction motors operating as self excited induction generators," IEE Proceedings-C, Vol. 140, September 1993.

[13] Sridhar, L., B. Singh, C. S. Jha, and B. P. Singh, "Analysis of a self excited induction generator feeding induction motor load," IEEE Transaction on Energy Conversion, Vol. 9, No. 2, June 1994.

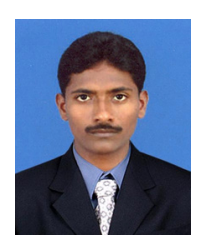

Sasikumar.M received the B.E degree in electrical and electronics engineering from K.S.Rangasamy College of Technology, Madras University, India in 1999, and the M.Tech degree in power electronics from VIT University, in 2006. Currently, he is a Lecturer in Jeppiaar Engineering College, Anna University, Chennai, he is also a Research Scholer in Sathyabama University, Chennai. His research interests are the power electronics, AC motor drives and wind energy systems.

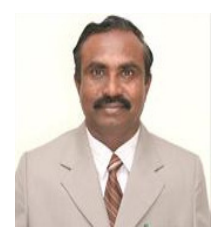

Dr.S.Chenthur Pandian (M - 41277581) was born in tamilnadu, India on April 19, 1959. He graduated from the institution of engineers, calcuta (India) and received his post graduate degree from Punjab University, Chandigarh (India). He has obtained his Ph.d. degree from periyar university, salem, tamilnadu, India.Currently he is working as a Principal in Dr.Mahalingam College of Engineering \& Technology, Udumalai Road, Pollachi - 642003. Tamilnadu, India. His areas of interests are Electrical and electronics engineering. His research areas are power system, power electronics, neural network, fuzzy logic, Neuro - fuzzy systems. Dr. pandian is a member of ISTE, FIE, MIEEE. Presently guiding 16 research scholars in various universities. 